\title{
Fetoscopic laser valve ablation in the posterior urethral valve case with intrauterine diagnosis
}

\author{
Selahattin Kumru' ${ }^{1}$ (D), Serdar Kaya² \\ ${ }^{1}$ Perinatology Division, Department of Obstetrics and Gynecology, Faculty of Medicine, Akdeniz University, Antalya, Turkey \\ ${ }^{2}$ Perinatology Division, Department of Obstetrics and Gynecology, Bağcllar Training and Research Hospital, University of Health Sciences, Istanbul, Turkey
}

\begin{abstract}
Objective: We aimed to present the procedure of intrauterine percutaneous fetoscopic laser valve ablation performed on a fetus diagnosed with lower urinary tract obstruction.

Case: Bilateral hydroureteronephrosis, dilated bladder and oligo/ anhydramnios were found in the fetal ultrasonography examination of a 21-year-old pregnant woman who did not have regular followups, and the lower urinary tract obstruction consistent with the posterior urethral valve was considered in the case. The patient who was found to have poor prognosis as a result of vesico synthesis carried out consecutively was informed about the follow-up and treatment options, and the posterior urethral valve ablation was performed by the percutaneous fetoscopic laser on 27 weeks of gestation. The amniotic fluid was at normal levels after the procedure, and the labor was carried out at term. The newborn with elevated postpartum creatinine was diagnosed with stage 2 renal failure, but dialysis was not required during the follow-ups. The newborn was discharged for outpatient follow-up upon the reduced creatinine levels.

Conclusion: By taking the survival enhancing effect of the intrauterine intervention into account in the presence of lower urinary tract obstruction, we considered that intrauterine intervention can be an option in the cases who prefer to continue their pregnancies. The families should be informed in detail about the benefits and risks of intrauterine intervention to repair the obstruction.
\end{abstract}

Keywords: Posterior urethral valve, lower urinary tract obstruction, fetoscopic laser ablation.

\section{Introduction}

Lower urinary tract obstruction (LUTO) which may be an important reason for fetal morbidity and mortality by leading to oligohydramnios and pulmonary hypoplasia is

\section{Özet: İntrauterin tanı alan posterior üretral valv olgusunda fetoskopik lazer valv ablasyonu}

Amaç: Alt üriner sistem obstrüksiyonu tanısı alan bir fetüse uygulanan intrauterin perkütan fetoskopik lazer valv ablasyonu işlemini sunmayı amaçladık.

Olgu: Yirmi bir yaşında, düzenli takipleri olmayan gebenin fetal ultrasonografik değerlendirilmesinde bilateral hidroüreteronefroz, dilate mesane, oligo/anhidramniyoz saptand 1 ve olguda posterior üretral valv ile uyumlu alt üriner sistem obstrüksiyonu düşünüldü. Ardışı uygulanan vezikosentez sonucu kötü prognozlu saptanan hastaya, takip ve tedavi seçenekleri hakkında bilgi verildi ve 27 . gebelik haftasında perkütan fetoskopik lazer ile posterior üretral valv ablasyonu yapıldı. İşlem sonrası amniyon sıvısı normal sınırda seyretti ve miadında doğum gerçekleşti. Postpartum kreatinin yüksekliği olan yenidoğana evre 2 böbrek yetmezliği tanısı konuldu ve takiplerinde diyaliz ihtiyacı olmadı. Kreatinin değerleri gerileyen yenidoğan ayaktan takip edilmek üzere taburcu edildi.

Sonuç: Alt üriner sistem obstrüksiyonu varlığında intrauterin müdahalenin sağkalımı artırıcı etkisi dikkate alınarak gebeliğin devamını isteyen olgularda seçenek olabileceği olabileceğini düşünüyoruz. Aile obstrüksiyonun düzeltilmesine yönelik intrauterin müdahalenin fayda ve riskleri hakkında ayrıntılı bilgilendirilmelidir.

Anahtar sözcükler: Posterior üretral valv, alt üriner sistem obstrüksiyonu, fetoskopik lazer ablasyon.

Correspondence: Serdar Kaya, MD. Perinatology Division, Department of Obstetrics and Gynecology, Bağcllar Training and Research Hospital, University of Health Sciences, Istanbul, Turkey. e-mail: kayaserdar75@hotmail.com / Received: May 28, 2020; Accepted: July 24, 2020

Please cite this article as: Kumru S, Kaya S. Fetoscopic laser valve ablation in the posterior urethral valve case with intrauterine diagnosis. Perinatal Journal 2020;28(3):206-211. doi:10.2399/prn.20.0283004 
are diagnosed prenatally. ${ }^{[2]}$ LUTO can also be defined as the bladder outlet obstruction. While posterior urethral valve (PUV) (68\%), urethral atresia (28\%) and urethral stenosis $(10 \%)$ are the most common reasons for LUTO, anterior urethral valve, ureterocele and megaloureter are the rare reasons for LUTO. It was reported that the anomaly blocking the urinary flow in PUV is the "congenital obstructive urethral membrane" which develops during the embryonic period. ${ }^{[1]}$ Independent from the etiology, the distal obstruction of the urinary tract causes urinary flow to decrease and leads to urinary congestion proximal to the lesion. In the selected cases among PUV cases, vesicoamniotic shunting and fetal cystoscopy were offered as the procedure options to decrease fetal mortality and morbidity, and it was suggested that the procedure decreased fetal mortality and limited or repaired renal damage. ${ }^{[3,4]}$ In the current report, we aimed to present a PUV case that we performed percutaneous fetoscopic laser ablation.

\section{Case Report}

A 21-year-old patient, who was pregnant for the first time and did not undergo routine gestational follow-ups and was referred to our clinic at 25 weeks of gestation when fetal pyelectasis was found at 24 weeks of gestation, was evaluated. Oligo/anhydramnios, dilated fetal bladder, increased wall thickness and keyhole sign were found in the ultrasonography examination (Fig. 1). The right renal pelvis was $23 \mathrm{~mm}$ and the left renal pelvis was $31 \mathrm{~mm}$, and it was observed that there was advanced pelvicalyceal dilatation and renal parenchyma got thinner (bilateral hydronephrosis) and hyperechogenic. It was considered that the condition was consistent with PUV. It was found in the urinalysis results obtained by two vesico syntheses conducted with 48-hour interval that the prognosis was poor ${ }^{[5]}$ (Table 1). The amniocentesis was performed due to the increased chromosomal disorders in the lower urinary tract obstructions and the chromosomal analysis result was reported as normal karyotype. The family was informed about LUTO, oligo/anhydramnios and potential complications (renal damage, pulmonary hypoplasia, perinatal mortality, structural deformity, preterm labor). They were informed about conservative approach, gestational termination and intrauterine procedure and the options were offered. It was reported that the intervention was not a routine procedure in such a case and it will not
Table 1. Fetal urinalysis results and prognostic criteria of the case.

\begin{tabular}{lccc} 
& $\begin{array}{c}\text { Analysis } \\
\text { results }\end{array}$ & $\begin{array}{c}\text { Good } \\
\text { prognosis }^{[5]}\end{array}$ & $\begin{array}{c}\text { Poor } \\
\text { prognosis }^{[5]}\end{array}$ \\
\hline Sodium & $106 \mathrm{mEq} / \mathrm{L}$ & $<90 \mathrm{mEq} / \mathrm{L}$ & $>100 \mathrm{mEq} / \mathrm{L}$ \\
\hline Chlorine & $90 \mathrm{mEq} / \mathrm{L}$ & $<80 \mathrm{mEq} / \mathrm{L}$ & $>90 \mathrm{mEq} / \mathrm{L}$ \\
\hline Calcium & $9 \mathrm{mg} / \mathrm{dL}$ & $<7 \mathrm{mg} / \mathrm{dL}$ & $>8 \mathrm{mg} / \mathrm{dL}$ \\
\hline Osmolality & $219 \mathrm{mOsm} / \mathrm{L}$ & $<180 \mathrm{mOsm} / \mathrm{L}$ & $>200 \mathrm{mOsm} / \mathrm{L}$ \\
\hline B2-microglobulin & $15 \mathrm{mg} / \mathrm{L}$ & $<6 \mathrm{mg} / \mathrm{L}$ & $>10 \mathrm{mg} / \mathrm{L}$ \\
\hline Total protein & $129 \mathrm{mg} / \mathrm{dL}$ & $<20 \mathrm{mg} / \mathrm{dL}$ & $>40 \mathrm{mg} / \mathrm{dL}$ \\
\hline
\end{tabular}

repair current renal damage, but that it may increase the survival rate by providing improvement in the fluid of the baby. As the family wanted to continue the pregnan$\mathrm{cy}$ and requested the procedure to increase the survival rate, it was decided to perform percutaneous fetoscopic laser ablation at 27 weeks of gestation. After the maternal epidural anesthesia, fentanyl $(15 \mu \mathrm{g} / \mathrm{kg})$ and pancuronium $(2 \mathrm{mg} / \mathrm{kg})$ were administered to provide fetal anesthesia and inactivity. ${ }^{[6]}$ After performing appropriate maternal abdominal skin incision, surgical sheath with $3.3 \mathrm{~mm}$ curve (11540 KEK, Karlz Storz, Tuttlingen, Germany) was inserted via ultrasonographic guidance and fetal bladder was entered on craniocaudal direction. Ureteral orifices, trabeculation on the bladder wall and bladder neck were displayed (Supplementary material: S-Video 1. The laser ablation procedure and imaging dilated posterior uretbra). After the dilated posterior urethra was found, Nd-YAG laser ablation (neodymium-yttriumaluminum-garnet) was performed on the membranous

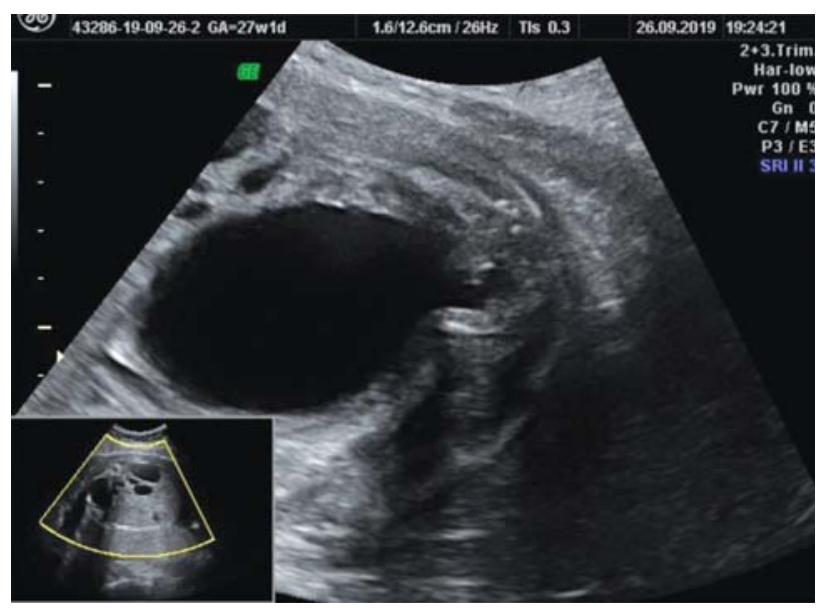

Fig. 1. Dilated bladder and posterior urethra. 
formation considered to cause obstruction in this area and to be posterior urethral valve, and urethral passage was ensured (Supplementary material: S-Video 2. The ablation of obstructive membrane by laser). It was observed that the bladder became smaller and amniotic fluid increased after the procedure, and the procedure was completed without any complication. While amniotic fluid was within normal limits during entire pregnancy according to the follow-ups after the procedure, the diameters of bladder and renal pelvis reduced and no further problem occurred. When it was 39 weeks and 2 days, a male fetus with a weight of 3270 and 9/10 Apgar score was delivered. The newborn without any respiratory distress was hospitalized at the neonatology clinic with the diagnosis of stage 2 kidney failure ${ }^{[7]}$ upon the elevated creatinine levels (creatinine: $3.15 \mathrm{mg} / \mathrm{dl}$ ). In the urinary ultrasonography examination conducted on the 5th postpartum day of the newborn, grade III-IV pelvicalyceal dilatation on the right kidney and grade II-III pelvicalyceal dilatation on the left kidney and many cortical cysts in both kidneys were observed, and it was found that the right renal pelvis was $7 \mathrm{~mm}$ and the left renal pelvis was $8 \mathrm{~mm}$. It was decided to perform complementary surgery for the newborn who was evaluated by the council established by the neonatology, pediatric surgery and pediatric nephrology clinics and considered to have partial obstruction. Posterior urethral valve ablation was performed by laser under the general anesthesia on the first postpartum month. With the regressing creatinine levels $(2.15 \mathrm{mg} / \mathrm{dl})$ in the follow-ups, the newborn was discharged for outpatient follow-up by calling for check-up 2 weeks later in terms of urinary ultrasound, kidney function and urinary tract infection follow-up by the pediatric nephrology clinic.

\section{Discussion}

Despite its low incidence, LUTO has a significant position among health problems associated with obstructive uropathies during perinatal period and childhood. ${ }^{[8]}$ The natural course of LUTO depends on the grade of bladder outlet obstruction (complete or partial) and the week of gestation that it develops. ${ }^{[9]}$ The findings of the obstructive uropathy appear during the earlier weeks of gestation in complete obstruction cases. Megacystis in the first trimester is an explicit ultrasonographic finding. Thickness in bladder wall, dilated posterior urethra (keyhole sign), hydroureteronephrosis, oligohydram- nios and sometimes anhydramnios are the other ultrasonographic findings. ${ }^{[1]}$ The sensitivity and specificity of ultrasonography in the diagnosis of LUTO are $85 \%$ and $80 \%$, respectively. ${ }^{[9]}$ The obstruction in the urinary flow prevents urine to reach amniotic cavity and causes oligo/anhydramnios. Amniotic fluid has a significant role in the development of lungs being particularly explicit in the canalicular phase between 16 and 28 weeks of gestation. ${ }^{[1]}$ The pulmonary hypoplasia associated with anhydramnios is the most important complication developing due to the loss of urinary flow towards amniotic cavity, and it was reported that the oligohydramnios which develops in pregnancies before 25 weeks of gestation and takes more than 2 weeks has higher mortality. ${ }^{[10]}$ The obstruction of urinary flow causes severe damage in both bladder and kidney associated with urinary retention as well as pulmonary hypoplasia. Oligohydramnios develops at the second trimester in $95 \%$ of the cases approached conservatively and mortality is observed in $45 \%$ of them while $25-30 \%$ of the surviving cases develop end-stage kidney failure which requires dialysis and renal transplantation until 5 years old. ${ }^{[4,11,12]}$

The selection of cases for intervention among LUTO cases has been a significant challenging problem. The algorithm for the assessment of LUTO cases is given Fig. 2. ${ }^{[13]}$ While the presence of severe hydronephrosis and oligohydramnios determines the severity of the disease, some problems are confronted in the evaluation of renal function. Some authors indicate fetal urinary biochemistry as the marker of renal function $^{[14]}$ while some other authors reported that fetal serum beta2-microglobulin is a better marker. ${ }^{[0,15]}$ Expectant approach may be recommended for stage 1 cases who have normal renal function (fetal urinary biochemistry with good prognosis, absence of renal cyst/dysplasia) and normal amniotic fluid. It is believed that the intervention on stage 2 fetuses, who have bilateral hydronephrosis and oligohydramnios but whose renal functions are normal, brings benefit. It is remarked that this intervention can prevent severe pulmonary hypoplasia and potentially renal functions to get worse. In stage 3 cases who developed oligo/anhydramnios, severe bilateral hydronephrosis, abnormal renal function and renal dysplasia, intrauterine intervention is not expected to repair renal functions but decreasing pulmonary problems associated with oligohydramnios and related mortality is of priority con- 


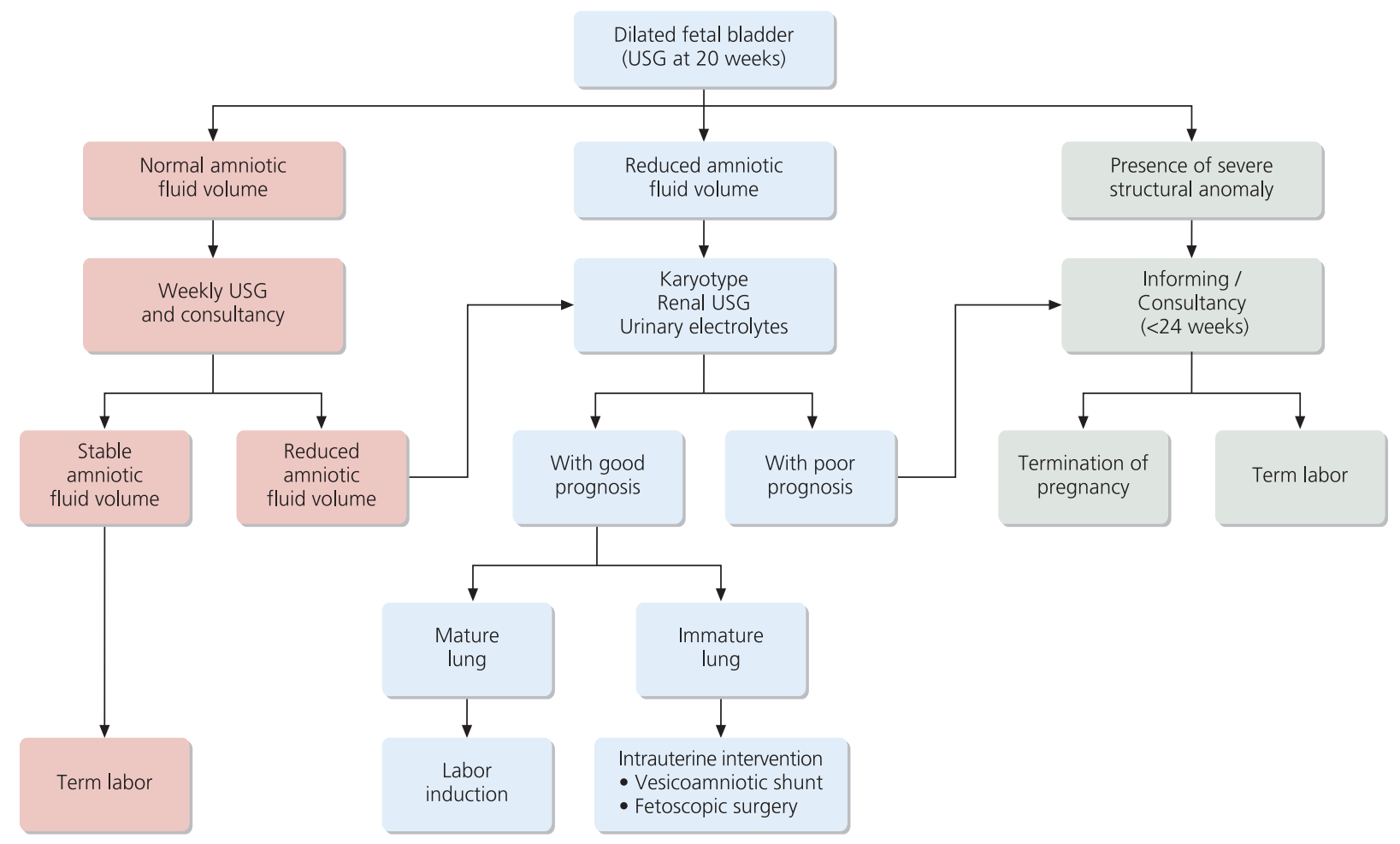

Fig. 2. The algorithm for the patient selection and assessment of LUTO cases for intervention. ${ }^{[13]}$

cern. $^{[1,16]}$ The management of LUTO cases by their stages is shown in Table $2 .{ }^{[17]}$ Our case had oligo/anhydramnios and hydronephrosis. We observed that the consecutive fetal urinalysis had poor prognosis. We informed the patient about the follow-up and treatment options. However, when we found out that amniotic fluid level was severely reduced (oligo/anhydramnios), we decided to carry out the procedure upon the request and approval of the family in order to maintain pulmonary development and increase perinatal survival by decreasing anhydramnios-related complications.

It was shown in the animal trials that the removal of the bladder obstruction prevents pulmonary hypoplasia and increase survival rate as it provides normal amniotic fluid production as well as it prevents progressive renal dysplasia. ${ }^{[4,18]}$ Therefore, vesico-amniotic sunt has

Table 2. Fetal management according to LUTO stages. ${ }^{[17]}$

\begin{tabular}{|c|c|c|c|}
\hline LUTO stage & Stage 1 (mild) & $\begin{array}{c}\text { Stage } 2 \text { (severe) } \\
\text { (Renal function is protected) }\end{array}$ & $\begin{array}{c}\text { Stage } 3 \text { (severe) } \\
\text { (Abnormal renal function findings) }\end{array}$ \\
\hline Amniotic fluid volume & Normal & $\begin{array}{l}\text { Oligohydramnios or } \\
\text { anhydramnios }\end{array}$ & $\begin{array}{l}\text { Anhydramnios (sometimes } \\
\text { oligohydramnios) }\end{array}$ \\
\hline Fetal kidney echogenicity & Normal & Hyperechogenic & Hyperechogenic \\
\hline Fetal cortical cyst / Renal dysplasia & Not available & Not available & Available \\
\hline Fetal urinary biochemistry & With good prognosis & With good prognosis & With poor prognosis \\
\hline \multirow[t]{2}{*}{ Fetal intervention } & Not indicated & $\begin{array}{l}\text { Indicated (to prevent pulmonary hypoplasia } \\
\text { and severe renal damage) }\end{array}$ & $\begin{array}{l}\text { It may be indicated to prevent } \\
\text { pulmonary hypoplasia }\end{array}$ \\
\hline & & & $\begin{array}{l}\text { Not indicated to prevent } \\
\text { renal damage. }\end{array}$ \\
\hline
\end{tabular}


become one of the most common antenatal treatment options for the obstructive uropathy. ${ }^{[4]}$ However, its protective effect on the long-term renal functions could not be shown although it increased the survival rate. ${ }^{[11]}$ In the children who underwent intrauterine shunt due to PUV, the mortality rate was found $43 \%$ during mean 54-month of follow-up and the progress to end-stage renal failure was $63 \%$ before puberty. ${ }^{[19]}$ Despite all efforts, it was found that the rate of progress to endstage renal failure has not changed in the children with PUV in the last 25 years. ${ }^{[1]}$ In addition, the problems such as the dislocation or obstruction of shunt are observed as the complications of vesicoamniotic shunt procedure. Quintero et al. reported fetal cystoscopy as a new diagnosis and treatment option as it provides a better evaluation, presents the underlying obstruction reason (PUV, urethral atresia, etc.) better and enables to conduct a permanent treatment. ${ }^{[20]}$ Despite its advantages, it has some disadvantages such as being more invasive procedure and observing complications such as urological fistula more than vesicoamniotic shunt. When we reviewed the fetal cystoscopy case reports in the literature, we have seen that the posterior urethral valve destruction can be done technically with success in $50 \%$ of the cases by laser fulguration and $70 \%$ neonatal survival rate is obtained, and that the laser ablation is the best option compared to the other options. ${ }^{[9]}$ Sanenes et al. obtained 53\% 2-year survival rate by laser fulguration of PUV in 50 fetal cystoscopy cases which had LUTO, and they reported $73 \%$ normal renal function among living fetuses, and they concluded that the fetal cystoscopy is a diagnostic method with $91 \%$ accuracy and a potential management option in appropriate cases. ${ }^{[2]]}$ Martinez et al. did not observe pulmonary hypoplasia in any $11 \mathrm{PUV}$ cases that they performed fetal cystoscopy and PUV ablation and reported $27 \%$ renal failure. ${ }^{[2]}$ Ruano et al. conducted their study with 23 PUV patients with severe LUTO, and they found the rates of survival and infants having normal renal functions significantly higher in 11 patients who underwent fetoscopic laser ablation than 12 patients who preferred expectant approach, and they concluded that the treatment of PUV by fetoscopic laser ablation could prevent renal function to get worse and improve postnatal outcomes. ${ }^{[6]}$ In a multi-center study comparing vesicoamniotic shunt and fetal cystoscopy in patients with PUV, the authors found improvement in 6-month survival rate and renal func- tion in the patients who underwent fetal cystoscopic laser ablation although the case number was low, and they observed improvement only in 6-month survival rate but no impact on renal function in the vesicoamniotic shunt group. ${ }^{[23]}$ The studies on fetal intervention in LUTO have low numbers of cases and limited followup data, and they differ from each other in terms of procedure criteria. ${ }^{[17]}$

In our case, we observed that renal function is affected during intrauterine period and we confirmed it by postpartum examinations. Despite the affected renal function, the newborn did not have pulmonary problems. Although current renal damage was not repaired, we believe that the laser procedure removing urinary obstruction and providing urinary flow from bladder and therefore amniotic fluid being within normal limits have a significant contribution to the development of lungs.

\section{Conclusion}

Lower urinary tract obstruction is a significant morbidity and mortality reason during both prenatal and postnatal periods. Although the impact of intrauterine intervention on the long-term renal outcomes cannot be shown clearly, it can be offered as an option to the families who prefer to continue their pregnancies after providing consultancy about the potential benefits and risks considering that the procedure increases the survival rate by elevating the amniotic fluid volume.

Conflicts of Interest: No conflicts declared

\section{References}

1. Farrugia MK. Fetal bladder outlet obstruction: embryopathology, in utero intervention and outcome. J Pediatr Urol 2016;12: 296-303. [PubMed] [CrossRef]

2. Malin G, Tonks AM, Morris RK, Gardosi J, Kilby MD. Congenital lower urinary tract obstruction: a population-based epidemiological study. BJOG 2012;119:1455-64. [PubMed] [CrossRef]

3. Johnson MP, Bukowski TP, Reitleman C, Isada NB, Pryde PG, Evans MI. In utero surgical treatment of fetal obstructive uropathy: a new comprehensive approach to identify appropriate candidates for vesicoamniotic shunt therapy. Am J Obstet Gynecol 1994;170:1770-6. [PubMed] [CrossRef]

4. Welsh A, Agarwal S, Kumar S, Smith RP, Fisk NM. Fetal cystoscopy in the management of fetal obstructive uropathy: experience in a single European centre. Prenat Diagn 2003;23: 1033-41. [PubMed] [CrossRef] 
5. Mann S, Johnson MP, Wilson RD. Fetal thoracic and bladder shunts. Semin Fetal Neonatal Med 2010;15:28-33. [PubMed] [CrossRef]

6. Ruano R, Duarte S, Bunduki V, Giron AM, Srougi M, Zugaib M. Fetal cystoscopy for severe lower urinary tract obstruction - initial experience of a single center. Prenat Diagn 2010;30: 30-9. [PubMed] [CrossRef]

7. Kidney Disease: Improving Global Outcomes (KDIGO) Acute Kidney Injury Work Group, KDIGO clinical practice guideline for acute kidney injury. Kidney Int Suppl 2012;2:1-138. [CrossRef]

8. Agarwal SK, Fisk NM. In utero therapy for lower urinary tract obstruction. Prenat Diagn 2001;21:970-6. [PubMed] [CrossRef]

9. Ruano R. Fetal surgery for severe lower urinary tract obstruction. Prenat Diagn 2011;31:667-74. [PubMed] [CrossRef]

10. Kilbride HW, Yeast J, Thibeault DW. Defining limits of survival: lethal pulmonary hypoplasia after midtrimester premature rupture of membranes. Am J Obstet Gynecol 1996;175: 675-81. [PubMed] [CrossRef]

11. Nassr AA, Shazly SAM, Abdelmagied AM, Araujo Júnior E, Tonni G, Kilby MD, et al. Effectiveness of vesicoamniotic shunt in fetuses with congenital lower urinary tract obstruction: an updated systematic review and meta-analysis. Ultrasound Obstet Gynecol 2017;49:696-703. [PubMed] [CrossRef]

12. Morris RK, Malin GL, Khan KS, Kilby MD. Antenatal ultrasound to predict postnatal renal function in congenital lower urinary tract obstruction: systematic review of test accuracy. BJOG 2009;116:1290-9. [PubMed] [CrossRef]

13. Smith-Harrison LI, Hougen HY, Timberlake MD, Corbett ST. Current applications of in utero intervention for lower urinary tract obstruction. J Pediatr Urol 2015;11:341-7. [PubMed] [CrossRef]

14. Miguelez J, Bunduki V, Yoshizaki CT, Sadek Ldos S, Koch V, Peralta CFA, et al. Fetal obstructive uropathy: is urine sampling useful for prenatal counselling? Prenat Diagn 2006;26: 81-4. [PubMed] [CrossRef]

15. Craparo FJ, Rustico M, Tassis B, Coviello D, Nicolini U. Fetal serum beta2-microglobulin before and after bladder shunting: a 2-step approach to evaluate fetuses with lower urinary tract obstruction. J Urol 2007;178:2576-9. [PubMed] [CrossRef]

16. Ruano R, Sananes N, Wilson C, Au J, Koh CJ, Gargollo P, et al. Fetal lower urinary tract obstruction: proposal for standardized multidisciplinary prenatal management based on disease severity. Ultrasound Obstet Gynecol 2016;48:476-82. [PubMed] [CrossRef]

17. Farrugia MK, Braun MC, Peters CA, Ruano R, Herndon CD. Report on The Society for Fetal Urology panel discussion on the selection criteria and intervention for fetal bladder outlet obstruction. J Pediatr Urol 2017;13:345-51. [PubMed] [CrossRef]

18. Harrison MR, Nakayama DK, Noall R, de Lorimier AA. Correction of congenital hydronephrosis in utero II. Decompression reverses the effects of obstruction on the fetal lung and urinary tract. Pediatr Surg 1982;17:965-74. [PubMed] [CrossRef]

19. Holmes N, Harrison MR, Baskin LS. Fetal surgery for posterior urethral valves: long-term postnatal outcomes. Pediatrics 2001;108:E7. [PubMed] [CrossRef]

20. Quintero RA, Johnson MP, Romero R, Smith C, Arias F, Guevara-Zuloaga F, et al. In-utero percutaneous cystoscopy in the management of fetal lower obstructive uropathy. Lancet 1995;346:537-40. [PubMed] [CrossRef]

21. Sananes N, Cruz-Martinez R, Favre R, Ordorica-Flores R, Moog R, Zaloszy A, et al. Two-year outcomes after diagnostic and therapeutic fetal cystoscopy for lower urinary tract obstruction. Prenat Diagn 2016;36:297-303. [PubMed] [CrossRef]

22. Martínez JM, Masoller N, Devlieger R, Passchyn E, Gómez $\mathrm{O}$, Rodo J, et al. Laser ablation of posterior urethral valves by fetal cystoscopy. Fetal Diagn Ther 2015;37:267-73. [PubMed] [CrossRef]

23. Ruano R, Sananes N, Sangi-Haghpeykar H, Hernandez-Ruano S, Moog R, Becmeur F, et al. Fetal intervention for severe lower urinary tract obstruction: a multicenter case-control study comparing fetal cystoscopy with vesicoamniotic shunting. Ultrasound Obstet Gynecol 2015;45:452-8. [PubMed] [CrossRef]

\footnotetext{
Supplementary materials:

Supplemental digital content is available for this article, which is available at www.perinataljournal.com

S-Video 1. The laser ablation procedure and imaging dilated posterior urethra.

S-Video 2. The ablation of obstructive membrane by laser.
}

Bu makalenin kullanım izni Creative Commons Attribution-NoCommercial-NoDerivs 3.0 Unported (CC BY-NC-ND3.0) lisansı aracılı̆̆ıyla bedelsiz sunulmaktadir. / This work is licensed under the Creative Commons Attribution-NonCommercial-NoDerivs 3.0 Unported (CC BY-NC-ND3.0) License. To view a copy of this license, visit http://creativecommons.org/licenses/by-nc-nd/3.0/ or send a letter to Creative Commons, PO Box 1866, Mountain View, CA 94042, USA. 